\title{
Stereotypes Towards Occupations in Turkey
}

\section{Ömer F. TUTKUN** Mustafa KOÇ**}

\begin{abstract}
The purpose of this research is to determine the stereotypes of Turkish people towards occupations. Survey research model was used as research method. Research was applied on 1161 participants in Turkey. Data was collected with Stereotypes Towards Occupations Questionnaire (STOQ) which has been developed by the researchers.
\end{abstract} According to results;

1- Positive stereotypes toward occupations are more than negative stereotypes.

2- Most Positive stereotypes toward occupations are reliable and hard working; most negative stereotypes are unreliable and forger.

3- Most reliable occupation is military profession, most polite occupation is banking, most generous occupation is medical doctor, most smart occupation is university instructor, most honest occupation is prayer leader and most hardworking occupation is worker; most bribery occupation is financier, most lazy occupation is civil servant, most unreliable and forger occupation is building contractor, most aggressive occupation is nurse and most vulgarity occupation is driver.

4- $\quad$ Most positive meaning has been given on teacher occupations. Most negative meaning has been given on building contractor. People.

Key Words: Stereotype, Prejudice, Attribution, Occupations, Turkish

Assist. Prof. Dr., Nigde University, Faculty of Education, oftutkun@ hotmail.com

** Assist. Prof. Dr., Sakarya University, Faculty of Education, kocmail12@ hotmail.com 


\section{SUMMARY}

Purpose and significance: People make use of some internal and external processes in order to interpret some cases and behaviors around in daily life. An observer's interpretation of an inner condition of an actor or himself by looking at the outer behavior is called as "attribution." There are several theoretical approaches in literature about how people's attribution constituted. Some of these theories have been suggested by Heider, Kelly, Jones-Davis, and Weiner. Stereotypes have affected place in social life and human relationships. The term "stereotype" can be explained as imagery of individual mentality about hisher complicated environment. The shape of this photo is partly cultural. People take cultural values where live in as they explain and tend to acquire the thing that fits the stereotype in which culture is shaped. To use this way to explain stereotypes is generally have wrong contents. The concept is also negative one. Stereotype is often used along with prejudice. Although these two terms are point at close concepts, they are different both functions and meanings. In this frame work stereotype is explained as a fixed, principal idea about a group whereas prejudice is explained as having believe negative characteristics or being insufficient towards race, ethnicity, sex, religion etc. In this context the purpose of this research is to determine the stereotypes of Turkish people towards occupations.

Methods: Survey research model was used as research method. The universe of research is Turkish People. Simple random sampling method has been used. Questionnaires were applied on 1161 participants in Turkey. Data was collected with "Stereotypes Towards Occupations Questionnaire (STOQ)." This questionnaire has been developed by researchers in order to determine stereotypes of Turkish people towards occupation. The scale was applied university students. Students were informed about how the questionnaire would be applied. The collected data have been tabled according to the range of frequency and percentages.

Results and Discussions: According to results of research, Turkish people have more positive stereotypes towards occupation than negative. Most positive meaning towards occupations is reliable, hardworking and clever. Most negative meaning towards occupations is unreliable, bribery and forger. These findings can be explained with possibly people's experiences with the occupations and professional person they are related to. In fact this is not only reason for this situation. One another reason can be people indirect experiences from different individual. An individual might shares a negative experience with professional although shelhe has no relation with that occupation. Then this individual may have negative image towards occupation. This is because of believing someone's words without questioning or investigating. In other words, "skepticism" has become a behavior that we should have in the culture we live. One other explanation can be about quality of occupation. The difficulty of customer satisfaction and the differences between the expectations of the customers and the quality of presentation of service which directly related people such as medical doctor or teacher may be caused these results. Another reason may be the different attitudes towards the people who benefit from these occupations. 
In conclusion, for choosing occupation process should begin in elementary education level. People should trained with qualify of how his her behavior should integrated with an occupation. This process begins understanding of occupational education program and continues during occupational life. Another factor about choose occupation should be personality features. Personality should be taken as a specific factor for directing to an occupation. In another words individual should construct his/her occupational identity and should perform the appropriate behaviors automatically beginning from the elementary education period. For professional and systematic direction all of the related individual, institutions and organizations should be occurred common understanding and action. As a result, occupational curriculum included not only cognitive and psychomotor objectiveslbehaviors and content but also emotional objectiveslbehaviors. It is also included objectiveslbehaviors about communication skills, especially human oriented occupational curriculum. 


\title{
Mesleklere Atfedilen Kalıp Yargılar
}

\author{
Ömer F. TUTKUN* $\quad$ Mustafa KOÇ ${ }^{* *}$
}

ÖZ. Bu araştırmanın amacı, Türkiye'de yaşayan insanların çeşitli mesleklere atfettiği kalıp yargıları belirlemektir. Araştırma tarama modelinde, Türk insanının mesleklere karşı taşıdıkları kalıp yargılarını betimlemeye yönelik bir çalışmadır. Araştırma 1161 katılımcı ile gerçekleştirilmiştir. Veriler araştırmacılar tarafından geliştirilen Mesleklere Atfedilen Kalıp Yargılar Anketi (MAKYA) aracılığıyla toplanmıştır. Araştırma sonucunda elde edilen bulgular şunlardır: 1- Mesleklere karşı olumlu kalıp yargılar, olumsuz kalıp yargılardan daha yüksektir. 2- Mesleklere atfedilen en olumlu kalıp yargılar, güvenilir ve çalışkan; en olumsuz kalıp yargılar, güvenilmez ve sahtekardır. 3- En güvenilir meslek askerlik, en kibar meslek bankacılık, en cömert meslek doktorluk, en akıllı meslek üniversite hocalığı, en dürüst meslek imamlık ve en çalışkan meslek işçilik; en rüşvetçi meslek maliyecilik, en tembel meslek memurluk, en güvenilmez ve en sahtekar meslek müteahhitlik, en saldırgan meslek hemşirelik ve en kaba meslek şoförlük olarak bulunmuştur. 4- En çok olumlu atıfların yapıldığı meslek öğretmenlik, en çok olumsuz atıfların yapıldığı meslek ise müteahhitliktir.

Anahtar Kelimeler: Kalıp yarg1, Önyargı, Atfetme, Meslekler, Türk İnsanı.

* Yrd.Doç.Dr., Niğde Üniversitesi Eğitim Fakültesi, oftutkun@hotmail.com

** Yrd.Doç.Dr., Sakarya Üniversitesi Eğitim Fakültesi, kocmail12@hotmail.com 


\section{GİRiș}

İnsan doğasının gelişimi ve insanının sosyal davranışları, içinde yaşadığı toplum ve kültürün etkisi ile şekillenir. Her insan kendi hayat biçimini bir toplum ve kültür içinde aktif olarak yaşayarak öğrenir. Bu süreçte içinde yaşadığı kültürün değerlerini içselleştirerek bir kimlik oluşturur. Bu kimlik bireyin fizyolojik ve psikolojik doğası ile sosyal grup, kurum ve oluşumların kaynaşmasının bir ürünüdür. Böylece birey içinde yaşadığı kültürde sosyal-kültürel bir kimlik kazanarak grup ve kurumlarla kaynaşır. Sosyalleşme olarak adlandırılabilecek bu durum, kişinin bilişsel, duygusal ve davranışsal gelişimini, hayatta alacağı sosyal roller ve mevkileri, bu rol ve yerlerin kendinden beklediği davranış ve becerileri, inançları, değerleri öğrenmesi, benimsemesidir (Ergun, 1994).

Günümüzde yaşanan hızlı teknolojik değişme ve gelişme süreci toplumsal, ailesel ve kişiler arası ilişkileri, yaşam biçimlerini ve kültürel yapıyı etkilemektedir. Bireyler bu gelişmelere uyum sağlamakta güçlük çekmektedirler. Bu nedenle bireyin çevresiyle etkili iletişim kurabilmesi ve uyum içinde olması günümüzde her zamankinden daha çok önemli hale gelmiş̧ir. Bunun nedeni soysal davranışın analizinde "sosyal uyarmanın fiziksel ve objektif özelliklerinin ve dinamiklerinin, sübjektif özellikler ve dinamiklerden daima daha az anlamlı görülmesidir" denilebilir (Bilgin, 1995: 151). Bireyin tepkisi ile fiziksel ya da objektif gerçeklik arasında araç rolü oynayan bilişsel süreçleri tanımaksızın, insan eylemlerini ve dolayısıyla sosyal davranışları açıklamak güçtür. İnsanlar yaşamlarında yer alan diğer insanları, grupları, toplumları bir takım türlere, tiplere ayırarak onları anlamlandırma eğilimindendirler. Kalıp yargı (stereotip) olarak adlandırılan bu eğilimler yaşamımızın pek çok yönünü ilgilendirir ve yaşamımızı etkiler.

İnsan içinde yaşadığı dünyada var olabilmek, karşılaştı̆̆ güçlüklerle baş edebilmek ve kendi değerler yapısını oluşturarak, kendi iç-kontrol süreçleri ile toplumsal kontrol süreçlerini tutarlı kılma eğilimindedir. İnsanın kendisini ve çevresini anlama isteği, onu yükleme (atfetme) süreçlerini kullanmaya yöneltir. Bundan sonraki bölümde insanın dış dünyayı anlamlandırmak için kullandığı süreçler, yükleme (atfetme) süreçleri ve kalıp yargı (stereotip) üzerinde durulmuştur.

\section{Yükleme (Atfetme) Kuramları}

İnsan yaşamı sayısız karmaşık öğe ile etkileşim içerisindendir. Bu nedenle, insan düşüncesi, kendi yaşantısını düzenli ve anlamlı hale koyma çabasındadır. İnsanlar gündelik yaşamda karşılaşmış oldukları bir takım olayları, davranışları anlamlandırmak için içsel ve dışsal bazı süreçlerden yararlanır. İnsanlar hem kendi davranışlarının, hem de başkalarının davranışlarının nedenleri hakkında çıkarsamalarda bulunurlar (Hogg ve Vaughan, 2007: 104). Bir gözlemcinin açık davranışa bakarak, bir aktörün ya da kendisinin içsel durumu hakkında yaptığ 1 çıkarıma yükleme (atfetme) denir (Dönmez, 1989: 95; Cüceloğlu, 2000: 515). Literatürde yer alan yükleme ile ilgili yaklaşımlardan bazıları aşağıda verilmiştir:

1- Heider'in Naif Psikoloji (sağduyu) Kuramı: Kurama göre, yükleme süreçlerinin temelinde, insanların davranışlarının altında yatan nedenleri anlama 
isteği vardır. İnsanlar, insan davranışlarına ilişkin nedensel kuramlar ortaya koyan sezgisel psikologlardır. Kuramın üç temel ilkesi vardır. 1- Davranışlarımız rastgele olmaktan çok güdülenmiş olduğundan, başkalarının davranışlarını güdeleyen etkenleri bulmaya çalışırız, 2- Çevremizi kontrol edebilmede anahtar etken, o çevre içindeki başkalarının nasıl davranacaklarını kestirebilmektir, 3- Davranışlara nedenler yüklerken kişisel etkenler ile çevresel etkenleri birbirinden ayırt ederiz (Akt. Hogg ve Vaughan, 2007: 104-106; Akt. Cüceloğlu, 2000: 515).

2- Kelley'nin Birlikte Değişim Kuramı: Kelly, insanların, davranışlarının nedenlerini belirlemeye çalışırken daha çok bilim adamları gibi hareket ettiklerini söyler. İnsanlar, önce davranışın hangi faktörlerle birlikte değiştiğini saptamaya ve sonra da bu faktöre nedensel bir rol atfetmeye çalışırlar. Kurama göre, nedensel yüklemelerle ilgili temel kavramlar, "birlikte değişme" ve "azaltma"dır. Birlikte değişme, birey hakkında birden fazla gözlem varsa geçerlidir. Eğer birey hakkında tek gözlem varsa, azaltma ilkesine göre nedensel yükleme yapılır. Birlikte değişme ilkesine göre bir davranış, zaman içinde kendisiyle birlikte değişme gösteren olası bir nedene yüklenir. İnsanlar, belli bir karar vermek için, bir kişinin bir eylemi potansiyel bir nedene bağlı olarak gerçekleştirmesiyle bağlantılı olarak, tutarlılık bilgisi, belirginlik bilgisi ve benzerlik bilgisi olmak üzere üç temel bilgi kümesini değerlendirirler (Akt. Hogg ve Vaughan, 2007: 107-109; Akt. Cüceloğlu, 2000: 516517).

3- Jones ve Davis'in Uyuşan Çıkarsamalar Kuramı: Jones ve Davis'in kuramı, insanların, bir kişinin davranışının onun kişisel bir özelliğine tekabül ettiğini, nasıl çıkarsadıklarını açıklar. Kişisel özellikle ilgili çıkarsama yapılabilecek iki temel faktör vardır. Bunlar, davranışın toplumsal olarak onaylanması ve bireyin davranışta bulunurken seçme özgürlüğünün bulunup bulunmamasıdır. Davranışın toplumsal kabulü yüksekse, gözlemcinin bireyin kişisel özellikleri hakkında çıkarsama yapması zorlaşır. Diğer taraftan sosyal değerlere aykırı davranışlar bireyin kişisel özellikleri ile ilgili çıkarsamalar yapılmasını kolaylaştırır. Gözlemci, bireyin davranışın hangi sonuçlarının niyete bağlı olduğunu belirlemelidir. Davranışın sonuçlarının belirli bir niyetle yapıldığını çıkarsayabilmek için, bireyin kendi davranışlarının sonuçlarını bildiğine, bu davranış için yeteneği olduğuna ve bu davranışı seçme özgürlüğüne sahip olduğuna inanmalıdır (Akt. Hogg ve Vaughan, 2007: 106-107).

4- Weiner'in Yükleme Kuramı: Weiner, insanların bir görevi başarıp başarmamalarına yüklenen nedenleri ve bunların sonuçları üzerinde durmuştur. İnsanlar, önce bir kimsenin başarılı olup olmadığını değerlendirir ve sonuca göre olumlu ya da olumsuz bir duygu geliştirirler. Daha sonra sergilenen eyleme bir neden yüklerler. Bu durum, gelecekteki eylemleri etkileyecek olan daha özgül duygular ve beklentiler oluşturur. İnsanlar, başarıya nedenler yüklerken üç performans boyutunu temele alırlar. Bunlar, 1- Konum: Eyleme kişi mi (iç neden) yoksa durum mu (dış neden) yol açmıştır? 2- Kalıcılık: İç ve dış nedenler kalıcı mıdır? 3- Kontrol edilebilirlik: Gelecek görev için yapılacak performans ne derecede kişinin kontrolündedir? (Akt. Hogg ve Vaughan, 2007: 111-112). 


\section{Kalıp Yargı (Stereotip)}

Kalıp yargılar, insanları bir takım türlere, tiplere bölmeyi ifade eden zihinsel yapıtlardır. Belli özelliklerin, her zaman gerçeğe ve olumlu kanıtlara dayanmaksızın belirli insanlarda ve gruplarda mevcut sanılmasını ifade eder. Bir başka deyişle, kafamızdaki düşünceleri sadeleştiren bir takım zihinsel süreçler, basma kalıp fikirlerdir. Kalıp yargının oluşma biçimi, kısmen kültüreldir. İnsanlar kültürü tanımladığı şekilde seçmekte ve kültürün biçimlendirdiği kalıp yargıya uygun seçtiği durumu, olguyu, algılama eğilimindedir. Kalıp yargılar genelde yanlış içeriklere dayandıklarından olumsuzluk içerirler (Karabayev ve Tutkun, 2001).

Kalıp yarg1 ve ön yargı terimleri yakın süreçlere işaret etmelerine rağmen, gerek işlevleri gerekse tanımları bakımından farklıdırlar. Kalıp yargı, bir grup hakkında sabit, zihinsel bir imaj olarak tanımlanabilir. Önyargı ise, varsayılan ırk, etnik köken, cinsiyet ve benzerinden bir tema alınarak bir kişi veya grubun olumsuz karakteristiklere sabit olduğu veya yetersiz olduğu hakkındaki inanç olarak tanımlanabilir (Robertson, 1987: 293). Literatürde önyarg1 teriminin farklı açıklamaları görülmektedir. Örneğin bir diğer açıklama da, önyarg1, bir olay, insan, durum hakkında yeterli bilgiye sahip olmaksızın, oldukça az kanıta dayanarak ya da hiçbir kanıt olmaksızın bir şeyin ya da kişinin iyi ya da kötü olduğuna ilişkin önceden geliştirilen düşünce, kanı veya tutumdur (Atkinson ve diğ., 2002: 720). Örneğin bir filmin sadece 5-10 saniyelik bölümünü görüp, filmin iyi yada kötü olduğu kanısına varmak gibi. Olumlu veya olumsuz olabilen bu tür kanılarda kişisel beklentiler ve duruma özgü etkenler etkilidirler. Son derece duygu ağırlıklı olan ve tersine kanıtlardan kolay kolay etkilenmeyen bu tür tutumlar, söz konusu kişilerin olumsuz, nahoş özelliklere sahip olduğu inancına dayanır. Önyargıda hem duygusal, hem de düşünsel öğeler bulunur. Genelleme ve bireyler arası farklılıkları görmezden gelme söz konusudur. Önyargı her zaman davranışlara yansımaz, kişi önyargılı tutumunu gizli de sürdürebilir. Önyargılar, cinsiyet, $\mathrm{rk}$, yaş, cinsel tercih, fiziksel ve zihinsel engellilere karşı olabilir (Budak, 2003: 567; Cüceloğlu, 2000: 543-549; Hogg ve Vaughan, 2007: 69, 76-77, 383-421; Robertson,1987: 293; Şerif ve Şerif, 1996: 662-668).

Kalıp yargı (stereotip), bir grubun üyelerine yönelik sabit, aşırı basitleştirilmiş, aşırı genelleştirilmiş, genellikle ön yargılı bir kanı, bir grubun tüm üyelerinin paylaştığı düşünülen olumlu veya olumsuz özellikleri taşıyan bilişsel bir şemadır. Bir diğer deyişle, bir sınıf ya da insan grubunun kişisel ya da fiziksel özellikler şemasıdır. Şema, bir kavram ya da uyaranın niteliklerine ilişkin bilgiyi temsil eden bilişsel yapıdır. Birbirleriyle ilintili düşünce, inanç ve tutum gibi bilişlerden oluşan bir kümedir. Bir kişiyi, bir durumu, bir olayı ya da bir yeri sınırlı bilgilerle kolay biçimde anlamlandırmamıza olanak sağlar (Atkinson ve diğ., 2002: 723; Hogg ve Vaughan, 2007: 72, 76). Örneğin, "bütün Yahudiler cimridir," "bütün gençler gürültülü müzik dinler,” gibi. Stereotipleştirme, kişilerin bireysel özelliklerini göz ardı eden ve hepsine ortak özellikler yükleyen bir durumdur. Korku, ekonomik sıkıntılar, günah keçisi bulma gibi çeşitli motivasyonları yansıtabilir (Budak, 2003: 699; Şerif ve Şerif, 1996: 654-656). 
Atkinson ve diğ.'ne (2002: 299-300) göre, kalıp yargı (stereotip), bütün bir insan sınıfının kişisel ya da fiziksel özellikleri hakkındaki çıkarsamalardır. Örneğin tipik bir Alman zeki, titiz ve ciddidir. Bu çıkarsamalar, aynı sınıfta yer alan bir çok insana nadiren uygun düşer ve toplumsal etkileşim bakımından çoğu kez yanlış yola sevk eder. Stereotiplerin hafiza üzerinde etkileri vardır. Bir kişi hakkında bilgi edinildiğinde, o kişiyi bazen bir stereotipe yerleştiririz ve sonra verilen bilgiyi stereotipimizdeki bilgi ile birleştiririz. Böylece kişi ile ilgili hafızamız kısmen stereotipten hareketle kurulur. Robertson'a (1987: 294) göre stereotip, bir grupla ilgili katı zihinsel bir imajdır. Örneğin ırkçılık ya da etnik ayrımcılık sosyal yaşamın kaçınılmaz bir boyutudur. Sterotiplerde imajların gerçekliği ile ilgili bir kaygı yoktur. Oluşan imaj, gerçekte öyle olmadığına ilişskin bir bilgi ya da yaşantıya sahip olunsa bile "istisnalar kaideyi bozmaz" kuralı dikkate alınır ve değiştirilmez.

Kalıp yargıların özellikleri şu şekilde sıralanabilir (Karabayev ve Tutkun, 2001): 1- Halk kültürüne, sıradan bilgiye dayandıklarından sözlü kültüre dahil ürünlerdir. Çeşitli gruplarca konuşularak edinilir, yayılır ve böylece davranış haline gelirler. 2- Tahmini veya duygusal bir durumu ifade eder ve değer yargısı niteliğindedirler. Kuşaktan kuşağa miras olarak geçerler. Kültürün muhtevasının bir parçasıdırlar. 3- Toplumdan, gelenek ve göreneklerden ya da kişisel eğilimlerimizden meydana gelirler ve basma kalıp değer yargıları biçiminde inanışlar yaratırlar. 4- Bunlar genellikle yanlış ve olumsuz yargı ve imajlardır. Gerçekten çok bir önyargıdırlar. Örneğin; Savaşçı İrlandalılar, Duygusal İtalyanlar, Duygusuz İsveçliler, Esrarengiz Şarklılar, Haylaz Zenciler gibi. Olumlu kalıp yargılar da vardır. Örneğin, Fransız kadınları entelektüeldir, Amerikan kadınları neşelidir gibi. 5- Kalıp yargılar kısmen basit bilgilerdir. Tartışma konusu olan sorun hakkında bilgi edinilmesini ve kişisel bir kanıyı oluşturmayı kolaylaştırmaktadırlar. Ayrıca toplumda köklü halde bulunan peşin hükümleri beslemektedirler. Böylece gerçeğe ters düşen durumları varmış gibi gösterirler. Örneğin, Türkiye'de erkekler birden fazla kadınla evlenebilir gibi. Ayrıca sübjektif nitelikleri objektif durumlara genellemeye de elverişlidirler. Örneğin, İngiliz politikası daima iki yüzlüdür gibi. Kalıp yargılar iki doğrultuda gelişirler:

1- Genelleştirme eğilimi: Kendisini tanımadığımız bir veya birkaç kişinin özelliklerini, onunla aynı kategoride bulunan bütün diğer kişilere yaymadır. Örneğin kısa boylu, haylaz bir çocuğu olan birinin, bütün kısa boylu çocukların haylaz olduğunu sanması gibi. Burada, bir imajı, yaşantı sahibi olduğumuz bir durum üzerinden, geniş bir kitle için fazla düşünmeden aniden, duygusal bir tutumla genelleştirme söz konusudur.

2. Özelleştirme eğilimi: Bir ülke, grup veya durumla ilgili sahip olduğumuz bir kanıyı o ülke, grup veya durumdan olan bir kişiye uygulamamızdır. Örneğin, yabancı bir ülkede bulunan bir Türk'ün, yabancılarla henüz hiç ilișkisi olmadan barbar olarak kabul edilmesi gibi. Bu durum birinciden daha çok uygulanır.

Kalıp yargıların toplumsal yaşamda ve insan ilişkilerinde etkili bir yeri vardır. Karabayev ve Tutkun (2001), kalıp yargılara bilişsel yaklaşımın, kişilik temelinde açıklamalara bir cevap olarak ortaya konduğunu belirtmektedirler. Kalıp yargılar, 
bilişsel bir sürecin ürünü olsa da kontrol edilemez ve dolayısıyla kişinin sorumlu tutulmayacağı kaçınılmaz sonuçlar değildir. Yeterli bilgiye sahip olduğu halde kalıp yargı kullanmak en azından bazı yönlerden kasıtlı bir davranış olarak görülebilir. Sosyal biliş açısından bakılırsa, bireylerin öz saygıları, bir ölçüde, bireyin sosyal sınıfi tarafindan belirlenmektedir. Bu bağlamda, insanlar, olumlu kimliklerini sürdürmek ve korumak amacıyla kendi gruplarını bir diğer gruba göre üstün görmek isteyebilirler. Kalıp yargıların yas grubu, sosyal sınıf, cinsiyet, milliyet, din orijini, meslek, aile durumu, politik eğilim gibi bir kimlik unsuru olduğu söylenebilir. Pek çok insan kalıp yargılarının kötü olduğunu ve otomatik olarak ön yargı gösterdiklerini ve yanlışlıklara yol açtıklarını düşünür. Şüphesiz, olabildiğince herkese bir birey, bir insan olarak davranılmalıdır. Ancak, eğer bir kişi ya da grup hakkında hiçbir bilgimiz yoksa, ait olduğu gruplar ya da kültür, onu daha doğru olarak algılamamızda genellikle yardımcı olurlar. Öz olarak kalıp yargıların, bir gerçekten çok bir ön yargı, bir fikir saplantısı veya bazen bir boş inanç ifade ettiklerini söyleyebiliriz.

\section{Meslek}

Meslek, bireyin kendini geliştirme ve gerçekleştirmede önemli bir etkendir. Bireyin yaşamında mutlu olması, bir anlamda, kendi özelliklerine uygun, doyum sağlayacağı meslek seçmesine bağlıdır (Doğramacı, 2008). Literatürde değişik meslek tanımları yer almaktadır. Kuzgun'a (1982) göre meslek, bir kimsenin hayatını kazanmak için yaptığı, kuralları toplumca belirlenmiş ve belli bir eğitimle kazanılan düzenli ve kurallı faaliyetler bütünüdür. Bir diğer tanıma göre (Meslek Rehberi, 2008) meslek, insanın yaşamını sürdürebilmek için icra ettiği ve genellikle yoğun bir eğitim, çalışma, bilgi birikimi, seçilen mesleğe bağlı olarak yetenek geliştirmeyi gerektiren ve tüm bu sürecin sonunda kişilerin kazandığı unvanın adidır.

Bilimsel anlamda meslek, özel bir uzmanlık alanı bilgisi, uzun ve yoğun bir akademik hazırlık gerektiren bir iş olarak tanımlanabilir. Günlük yaygın kullanımı ile meslek, bir kimsenin geçimini sağlamak üzere yaptı̆̆ iş̧ ya da uğraşı ifade eder. Bir başka deyişle meslek, insanların sosyal statüsüne bakılmaksızın sadece yaşamı sürdürmek için gerekli geliri sağlayan bir iş ya da uğraştır. Meslek en geniş tanımı ile "toplumdaki sosyal, ekonomik ve teknolojik yapının gerektirdiği bir iş bölümü sonucu ortaya çıan, bireyin ilgi ve kabiliyeti ile sosyal etkinliklere katılma gereksinimi ve toplumun bireyden sosyal ve ekonomik yaşamda sorumluluk yüklenmesi talebi sonucu ortaya çıkmış olan bir yaşamsal etkinlik olgusudur" (Budak, 2003: 401; Şahin, 2007: 262-263; Yılmaz, 2002: 309).

Meslek ve iş birbirinden farklı kavramlardır. Meslek, yukarıda belirtildiği gibi (Kuzgun, 1982), bir kimsenin hayatını kazanmak için yaptığı, kuralları toplumca belirlenmiş ve belli bir eğitimle kazanılan sistemli etkinlikler bütünüdür. Meslek, belli bir tür alanda etkinlikte bulunabilme gücüdür. İş ise, belli bir işyerinde sürdürülen benzer etkinlikler grubudur. Bir kimsenin mesleği olabilir, ama işi olmayabilir. Bir işin olması da bireyin mesleği olduğu anlamına gelmez. Günümüz dünyasında önemli olan bireyin meslek sahibi olmasıdır (Index, 2008; PsikoWeb, 
2008). Meslek etkinlikleri, birbirlerinden az çok farklı bireysel özellikler gerektirir ve yine bireylere az çok farklı doyumlar sağlar. Meslek seçimi, bir kimsenin, çeşitli meslekler arasından en iyi yapabileceğini düşündügü etkinlikleri içeren ve kendisine en üst düzeyde doyum sağlayacağına inandığı birine yönelmesidir. Bu yönelme kararının doğru ve yerinde olması bireyin ne istediğini ve neleri yapabileceğini çok iyi bilmesine bağlıdır (Meslek Seçimi, 2008).

Kuzgun (2008), meslek seçiminin, çağdaş bir toplumda özgür bir bireyin önemli gelişim görevlerinden biri olduğunu belirtmektedir. Bir bireyin herhangi bir konuda doğru seçim yapabilmesi için öncelikle neler istediğini ve bunları elde etmek için ne tür olanaklara sahip olduğunu bilmesi gerekir. Bireyin meslek seçimi gibi önemli bir kararı sağlık bir biçimde oluşturmasını etkileyen bazı etmenler vardır. Bunlar bireyin çalışma dünyası ve insan nitelikleri ile ilgili edinmiş olduğu bir takım inanç ve genellemelerdir. Birey öncelikle istediği mesleklerin kendi niteliklerine uygun olup olmadığını sorgulamalıdır. Bu çerçevede birey profesyonel yardım almalıdır. Ülkemizde mesleklerin toplumsal saygınlık düzeylerinin çok farklı oluşu, bireylerin tercihlerini belirlemelerinde önemli rol oynamaktadır. Bu durum hem bireyin mutsuz olmasına ve hem de aile ve ülke için ekonomik ve insan gücü kaybına yol açmaktadır.

Kağıtçıbaşı'na (1985: 296-298) göre, Türkiye'de genel değerler sistemine bağlı olarak, mesleklerin itibarı zaman içerisinde değişmektedir. Ayrıca, bireyin meslek seçiminde ilgi ve yetenek gibi bireysel faktörlerden daha çok, toplumsal faktörler etki etmektedir. Meslek seçiminde Kuzgun'a (1982) göre, mesleğin birey üzerindeki etkileri çok yönlü ve güçlü olabilmektedir. Özellikle ilgi ve yeteneklerine uygun olmayan meslekleri tercih edenler bu etkiyi daha da yoğun ve güçlü olarak hissedebilmektedir. Teknolojik ilerleme ve değişmeler sonucu, mesleklerin yürütülmesi daha uzun, zahmetli, ve daha yorucu bir eğitim gerektirmekte ve meslekte geriye dönüş gittikçe zorlaşmaktadır. Bir alanda kazanılan bilgi ve becerilerin başka bir alanda geçerli olması zayıflamaktadır. Bu nedenle, meslek seçiminin sağlıklı bir karar verilerek seçilmesi önem kazanmaktadır.

Ait olunan sosyo-ekonomik çevre ne olursa olsun, Türkiye'de gençlik başta ekonomi ve istihdam olmak üzere eğitim, sağlık, barınma beslenme, boş zamanları değerlendirme ve çeşitli geleneksel sorunlarla karşı karşıyadır. 1989 yılı kayıtlarına göre 15-24 yaş arası kayıtlı açık işsizlerin oranı $\% 53.5^{\prime}$ tir. Türkiye'de gençliğin en büyük sorunları arasında ilk sırada işsizlik yer almaktadır (Doğan 2007: 503-507). $\mathrm{Bu}$ durumun, ülkemizde bireylere bir mesleki beceri kazandırılamadığının bir göstergesi olduğu söylenebilir.

Mesleki gelişim süreci, okul öncesinden başlayıp, meslek yaşamının sonuna kadar süren bir süreçtir. Birey bu süreçte şu istendik davranışlarla donanık kılınmalıdır: 1- Değişik konulardaki yeteneklerini doğru, gerçekçi ve ayrıntılı olarak değerlendirebilme, 2- Bir meslekten neler beklediğini açık ve net bir biçimde ortaya koyabilme, 3- Mevcut seçenekleri inceleme, her birini beklentileri karşılama, var olan yetenek ve ekonomik olanaklarla ulaşabilme yeterliği açısından değerlendirme, 4- İstekleri ve beklentileri karşılama ve erişme olasılığı olanlara yönelme kararını verebilme (Kuzgun 2008). 
$\mathrm{Bu}$ araştırmada, ülkemiz insanlarının mesleklere ilişkin olumlu-olumsuz kalıp yargılarının (imajları) belirlenmesi amaçlanmıştır. Bir işi seçen ve yapan bireyin, o işin doğru yapılması için gerekli bilgi ve becerilere sahip olmasının yanı sıra, o işe karşı olumlu tutumlara da sahip olması gerekir. Bu durumun, hem iş sonucu ortaya çıkan hizmet ve ürünün niteliği hem de işi yapan kişinin iş doyumu, dolayısıyla mutluluğu açılarından önemli olduğu açıktır. Bu bağlamda, çalışma bulgularının bireylerin mesleklere karşı tutum oluşturmalarında ve mesleki eğitim programlarının duyuşsal hedef/davranışlarının ve buna yönelik içeriğin oluşturulmasında katkı sağlayacağı düşünülmektedir.

\section{Problem}

Araştırmada, Türk insanın mesleklere karşı taşıdıkları kalıp yargılar incelenmiş ve aşağıdaki sorulara cevap aranmıştır:

1- Mesleklere atfedilen kalıp yargılar nelerdir?

2- Atfedilen kalıp yargıların mesleklere göre dağılımı nasıldır?

3- Mesleklere atfedilen olumlu kalıp yargilar nelerdir?

4- Mesleklere yapılan olumsuz kalıp yargılar nelerdir?

\section{YÖNTEM}

Bu çalışma tarama modelinde, Türk insanının mesleklere karşı taşıdıkları kalıp yargıları belirlemeye yönelik betimsel bir araştırmadır.

\section{Çalışma Evreni}

Araştırmanın çalışma evreni, basit tesadüfi örnekleme yöntemi ile ulaşılan, 1161 katılımcıdan oluşmuştur. Araştırmada katılımcıların yaşadığı yerleşim birimi, cinsiyetleri, öğrenim durumu, gelir durumu, eğitim durumu gibi değişkenler dikkate alınmamıştır.

\section{Veri Toplama Araçları}

$\mathrm{Bu}$ araştırmada Türk insanının mesleklere karşı taşıdıkları kalıp yargıları belirlemeye yönelik araştırmacılar tarafindan geliştirilen bir anket kullanılmıştır. Anketin birinci bölümünde katılımcıların cinsiyeti, yaş grubu, eğitim durumu, gelir düzeyi ve oturdukları yerleşim birimi; ikinci bölümde ise meslek grubuna atfedilen 6 tanesi olumlu nitelikleri, diğer 6 tanesi olumsuz nitelikleri içeren 12 "sıfat" yer almaktadır. Bu sıfatlar içerisinde meslekleri en iyi biçimde nitelendirenlerin hangisi olduğu sorulmuştur. Literatürde yüzlerce mesleğin yer aldığ 1 gruplamalar mevcuttur (TOBB, 2008; Meslek Rehberi, 2008). Bu çalışmada, toplum tarafindan daha çok bilinen meslekler dikkate alınmıştır. Bu çerçevede bu çalışmada Meslek gruplarını, üniversite hocalığı, öğretmenlik, hakimlik, avukatlık, mühendislik, mimarlık, doktorluk, imamlık, bankacılık, gazetecilik, memurluk, askerlik, hemşirelik, şoförlük, esnaflık, polislik, işçilik, savcılık, maliyecilik ve müteahhit meslekleri oluşturmaktadır. Sıfatları ise, güvenilir, kibar, cömert, akıllı, çalışkan, dürüst olumlu sıfatları ile rüşvetçi, tembel, güvenilmez, sahtekar, saldırgan ve kaba olumsuz sıfatları oluşturmaktadır.

\section{Verilerin Toplanması ve Çözümlenmesi}

Anket Eğitim Fakültesi öğrencileri tarafından uygulanmıştır. Uygulama öncesi öğrencilere anketlerin nasıl uygulanacağı hakkında seminer verilmiştir. Araştırmada, katılımcıların yaşadığı yerleşim birimi, cinsiyetleri, öğrenim durumu, gelir durumu ve eğitim durumu gibi değişkenler analiz edilmemiştir. Araştırmaya katılmayı kabul eden katılımcılara, anketörler tarafından gerekli açıklamalar yapıldıktan sonra, ölçek verilmiş ve anında cevaplandırılması sağlanmıştır. Cevaplama sürecinde 
ortaya çıkan durumlara anketör müdahale etmiştir. Okuryazar olmayan katılımcılara açıklamalardan sonra anketör yardımı ile ölçek uygulanmış, verilen cevaplar tekrar kendilerine okunmuş ve onay alınmıştır. Uygulanan 1500 anketten amaca uygun cevaplanmayan formların çıkarılması sonucu, toplam 1161 katılımcının anketleri analize alınmıştır. Araştırmada toplanan veriler frekans ve yüzde dağılımlarına göre tablolaştırılarak yorumlamalara gidilmiştir.

\section{BULGULAR}

1- Mesleklere Atfedilen Kalıp Yargıların Dağılımı: Mesleklere atfedilen kalıp yargıların dağılımına ilişkin bulgular Tablo 1'de verilmiştir.

Tablo 1 Mesleklere Atfedilen Kalıp Yargıların Dağılımı

\begin{tabular}{|l|c|}
\hline Sifatlar & $\mathbf{\%}$ \\
\hline Güvenilir & 16,0 \\
\hline Çalışkan & 15,6 \\
\hline Güvenilmez & 10,2 \\
\hline Rüşvetçi & 9,4 \\
\hline Akıllı & 9,0 \\
\hline Sahtekar & 8,3 \\
\hline Kaba & 7,7 \\
\hline Dürüst & 6,4 \\
\hline Tembel & 5,8 \\
\hline Kibar & 5,3 \\
\hline Saldırgan & 4,0 \\
\hline Cömert & 2,2 \\
\hline
\end{tabular}

Mesleklere atfedilen kalıp yargıların neler olduğuna ilişkin bulgular Tablo 1'de verilmiştir. Buna göre meslek mensuplarının \%16's1 güvenilir, \%15,6'sı çalışkan, $\% 10,2$ 'si güvenilmez, \%9,4'ü rüşvetçi, \%9'u ak1llı, \%8,3'ü sahtekar, \%7,7'si kaba, $\% 6,4$ 'ü dürüst, $\% 5,8$ 'i tembel, $\% 5,3$ 'ü kibar, $\% 4$ 'ü saldırgan ve $\% 2,2$ 'si cömert bulunmuştur.

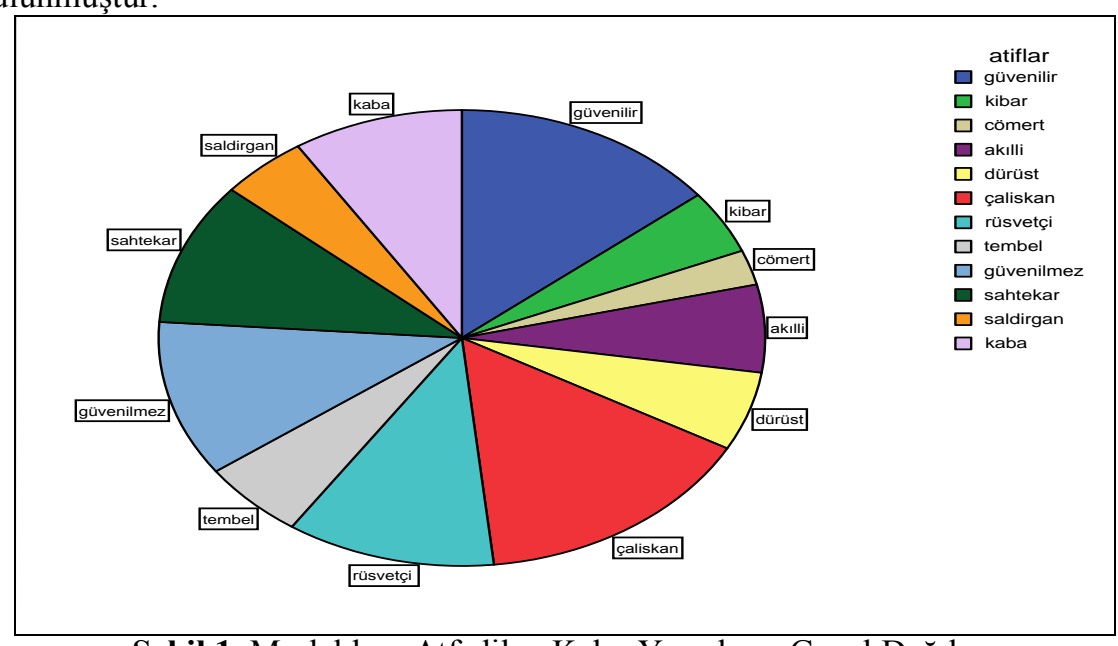

Şekil 1. Mesleklere Atfedilen Kalıp Yargıların Genel Dağılımı 
2- Atfedilen Kalıp Yargıların Mesleklere Göre Dağılımı: Atfedilen kalıp yargıların mesleklere göre dağılımına ilişkin frekans ve yüzdelikler Tablo 2'te verilmiştir.

Tablo 2 Atfedilen Kalıp Yargıların Mesleklere Göre Dağılımına İlişkin Frekans Ve Yüzdelikler

\begin{tabular}{|c|c|c|c|c|c|c|c|c|c|c|c|c|c|c|}
\hline & & & \multicolumn{12}{|c|}{ MESLEKLERE YAPILAN ATIFLAR } \\
\hline & & & güvenilir & kibar & cōmert & akilli & dürüst & çaliskan & rüsvetçi & tembel & güvenilmez & sahtekar & saldirgan & kaba \\
\hline \multirow[t]{40}{*}{ mesleker } & \multirow{2}{*}{$\begin{array}{l}\text { Ünivesnite } \\
\text { hocaligi }\end{array}$} & $\mathrm{N}$ & 159 & 84 & 5 & 193 & 26 & 142 & 21 & 34 & 75 & 14 & 8 & 32 \\
\hline & & $\%$ & $20,1 \%$ & $10,6 \%$ &, $6 \%$ & $24,3 \%$ & $3,3 \%$ & $17,9 \%$ & $2,6 \%$ & $4,3 \%$ & $9,5 \%$ & $1,8 \%$ & $1,0 \%$ & $4,0 \%$ \\
\hline & \multirow[t]{2}{*}{ ögretmenlik } & $\mathrm{N}$ & 222 & 53 & 17 & 117 & 76 & 159 & 21 & 82 & 16 & 7 & 10 & 13 \\
\hline & & $\%$ & $28,0 \%$ & $6,7 \%$ & $2,1 \%$ & $14,8 \%$ & $9,6 \%$ & $20,1 \%$ & $2,6 \%$ & $10,3 \%$ & $2,0 \%$ &, $9 \%$ & $1,3 \%$ & $1,6 \%$ \\
\hline & \multirow[t]{2}{*}{ hakimlik } & $\mathrm{N}$ & 281 & 28 & 6 & 97 & 152 & 31 & 60 & 19 & 56 & 22 & 9 & 32 \\
\hline & & $\%$ & $35,4 \%$ & $3,5 \%$ &, $8 \%$ & $12,2 \%$ & $19,2 \%$ & $3,9 \%$ & $7,6 \%$ & $2,4 \%$ & $7,1 \%$ & $2,8 \%$ & $1,1 \%$ & $4,0 \%$ \\
\hline & \multirow[t]{2}{*}{ av ukalik } & $\mathrm{N}$ & 72 & 29 & 11 & 10 & 44 & 62 & 153 & 13 & 130 & 151 & 19 & 9 \\
\hline & & $\%$ & $10,2 \%$ & $4,1 \%$ & $1,6 \%$ & $1,4 \%$ & $6,3 \%$ & $8,8 \%$ & $21,8 \%$ & $1,8 \%$ & $18,5 \%$ & $21,5 \%$ & $2,7 \%$ & $1,3 \%$ \\
\hline & \multirow[t]{2}{*}{ mühendisilik } & $\mathrm{N}$ & 38 & 36 & 18 & 161 & 33 & 245 & 42 & 46 & 82 & 75 & 11 & 6 \\
\hline & & $\%$ & $4,8 \%$ & $4,5 \%$ & $2,3 \%$ & $20,3 \%$ & $4,2 \%$ & $30,9 \%$ & $5,3 \%$ & $5,8 \%$ & $10,3 \%$ & $9,5 \%$ & $1,4 \%$ &, $8 \%$ \\
\hline & \multirow[t]{2}{*}{ mimarlik } & $\mathrm{N}$ & 69 & 75 & 18 & 178 & 48 & 216 & 29 & 29 & 65 & 52 & 9 & 5 \\
\hline & & $\%$ & $8,7 \%$ & $9,5 \%$ & $2,3 \%$ & $22,4 \%$ & $6,1 \%$ & $27,2 \%$ & $3,7 \%$ & $3,7 \%$ & $8,2 \%$ & $6,6 \%$ & $1,1 \%$ &, $6 \%$ \\
\hline & \multirow[t]{2}{*}{ doktorluk } & $\mathrm{N}$ & 211 & 46 & 7 & 87 & 33 & 120 & 124 & 18 & 47 & 27 & 28 & 45 \\
\hline & & $\%$ & $26,6 \%$ & $5,8 \%$ &, $9 \%$ & $11,0 \%$ & $4,2 \%$ & $15,1 \%$ & $15,6 \%$ & $2,3 \%$ & $5,9 \%$ & $3,4 \%$ & $3,5 \%$ & $5,7 \%$ \\
\hline & \multirow[t]{2}{*}{ imamlik } & $\mathrm{N}$ & 284 & 28 & 20 & 26 & 175 & 16 & 16 & 89 & 46 & 62 & 8 & 23 \\
\hline & & $\%$ & $35,8 \%$ & $3,5 \%$ & $2,5 \%$ & $3,3 \%$ & $22,1 \%$ & $2,0 \%$ & $2,0 \%$ & $11,2 \%$ & $5,8 \%$ & $7,8 \%$ & $1,0 \%$ & $2,9 \%$ \\
\hline & \multirow[t]{2}{*}{ bankacilik } & $\mathrm{N}$ & 79 & 106 & 6 & 71 & 37 & 145 & 103 & 41 & 85 & 58 & 17 & 45 \\
\hline & & $\%$ & $10,0 \%$ & $13,4 \%$ &, $8 \%$ & $9,0 \%$ & $4,7 \%$ & $18,3 \%$ & $13,0 \%$ & $5,2 \%$ & $10,7 \%$ & $7,3 \%$ & $2,1 \%$ & $5,7 \%$ \\
\hline & \multirow[t]{2}{*}{ gazetecilik } & $\mathrm{N}$ & 32 & 31 & 20 & 62 & 37 & 126 & 33 & 20 & 211 & 125 & 79 & 17 \\
\hline & & $\%$ & $4,0 \%$ & $3,9 \%$ & $2,5 \%$ & $7,8 \%$ & $4,7 \%$ & $15,9 \%$ & $4,2 \%$ & $2,5 \%$ & $26,6 \%$ & $15,8 \%$ & $10,0 \%$ & $2,1 \%$ \\
\hline & \multirow[t]{2}{*}{ memurluk } & $\mathrm{N}$ & 70 & 41 & 14 & 24 & 35 & 104 & 135 & 172 & 53 & 19 & 32 & 94 \\
\hline & & $\%$ & $8,8 \%$ & $5,2 \%$ & $1,8 \%$ & $3,0 \%$ & $4,4 \%$ & $13,1 \%$ & $17,0 \%$ & $21,7 \%$ & $6,7 \%$ & $2,4 \%$ & $4,0 \%$ & $11,9 \%$ \\
\hline & \multirow[t]{2}{*}{ askerlik } & $\mathrm{N}$ & 347 & 16 & 24 & 17 & 58 & 100 & 15 & 23 & 33 & 19 & 57 & 84 \\
\hline & & $\%$ & $43,8 \%$ & $2,0 \%$ & $3,0 \%$ & $2,1 \%$ & $7,3 \%$ & $12,6 \%$ & $1,9 \%$ & $2,9 \%$ & $4,2 \%$ & $2,4 \%$ & $7,2 \%$ & $10,6 \%$ \\
\hline & \multirow[t]{2}{*}{ hemsirelik } & $\mathrm{N}$ & 76 & 101 & 13 & 16 & 18 & 115 & 22 & 54 & 36 & 8 & 109 & 225 \\
\hline & & $\%$ & $9,6 \%$ & $12,7 \%$ & $1,6 \%$ & $2,0 \%$ & $2,3 \%$ & $14,5 \%$ & $2,8 \%$ & $6,8 \%$ & $4,5 \%$ & $1,0 \%$ & $13,7 \%$ & $28,4 \%$ \\
\hline & \multirow[t]{2}{*}{ söförlük } & $\mathrm{N}$ & 68 & 33 & 21 & 23 & 20 & 101 & 13 & 32 & 75 & 32 & 69 & 306 \\
\hline & & $\%$ & $8,6 \%$ & $4,2 \%$ & $2,6 \%$ & $2,9 \%$ & $2,5 \%$ & $12,7 \%$ & $1,6 \%$ & $4,0 \%$ & $9,5 \%$ & $4,0 \%$ & $8,7 \%$ & $38,6 \%$ \\
\hline & \multirow[t]{2}{*}{ esnaflik } & $\mathrm{N}$ & 46 & 43 & 44 & 56 & 47 & 103 & 34 & 31 & 130 & 142 & 22 & 95 \\
\hline & & $\%$ & $5,8 \%$ & $5,4 \%$ & $5,5 \%$ & $7,1 \%$ & $5,9 \%$ & $13,0 \%$ & $4,3 \%$ & $3,9 \%$ & $16,4 \%$ & $17,9 \%$ & $2,8 \%$ & $12,0 \%$ \\
\hline & \multirow[t]{2}{*}{ polislik } & $\mathrm{N}$ & 178 & 13 & 10 & 14 & 28 & 71 & 254 & 18 & 57 & 20 & 63 & 67 \\
\hline & & $\%$ & $22,4 \%$ & $1,6 \%$ & $1,3 \%$ & $1,8 \%$ & $3,5 \%$ & $9,0 \%$ & $32,0 \%$ & $2,3 \%$ & $7,2 \%$ & $2,5 \%$ & $7,9 \%$ & $8,4 \%$ \\
\hline & \multirow[t]{2}{*}{ isçlilik } & $\mathrm{N}$ & 57 & 19 & 29 & 12 & 41 & 451 & 7 & 74 & 31 & 10 & 18 & 44 \\
\hline & & $\%$ & $7,2 \%$ & $2,4 \%$ & $3,7 \%$ & $1,5 \%$ & $5,2 \%$ & $56,9 \%$ &, $9 \%$ & $9,3 \%$ & $3,9 \%$ & $1,3 \%$ & $2,3 \%$ & $5,5 \%$ \\
\hline & \multirow[t]{2}{*}{ savcilik } & $\mathrm{N}$ & 300 & 37 & 23 & 96 & 89 & 39 & 56 & 25 & 59 & 21 & 24 & 24 \\
\hline & & $\%$ & $37,8 \%$ & $4,7 \%$ & $2,9 \%$ & $12,1 \%$ & $11,2 \%$ & $4,9 \%$ & $7,1 \%$ & $3,2 \%$ & $7,4 \%$ & $2,6 \%$ & $3,0 \%$ & $3,0 \%$ \\
\hline & \multirow[t]{2}{*}{ maliyecilik } & $\mathrm{N}$ & 41 & 19 & 16 & 47 & 37 & 51 & 351 & 24 & 100 & 66 & 21 & 20 \\
\hline & & $\%$ & $5,2 \%$ & $2,4 \%$ & $2,0 \%$ & $5,9 \%$ & $4,7 \%$ & $6,4 \%$ & $44,3 \%$ & $3,0 \%$ & $12,6 \%$ & $8,3 \%$ & $2,6 \%$ & $2,5 \%$ \\
\hline & mühendis lik & $\mathrm{N}$ & 0 & 3 & 12 & 31 & 15 & 18 & 73 & 12 & 205 & 399 & 20 & 5 \\
\hline & & $\%$ & , $0 \%$ & , $4 \%$ & $1,5 \%$ & $3,9 \%$ & $1,9 \%$ & $2,3 \%$ & $9,2 \%$ & $1,5 \%$ & $25,9 \%$ & $50,3 \%$ & $2,5 \%$ &, $6 \%$ \\
\hline
\end{tabular}


Tablo 2'de mesleklere atfedilen kalıp yargılar incelenmiştir. $\mathrm{Bu}$ incelemede mesleklere en yüksek düzeyde atfedilen olumlu sifat ile en yüksek düzeyde atfedilen olumsuz sıfatlara yer verilmiştir. Buna göre, üniversite hocalığına en yüksek düzeyde atfedilen en olumlu sifat $\% 24$ akillı, en olumsuz sifat $\% 9,8$ güvenilmez; öğretmenlik mesleğine atfedilen en olumlu sifat \%28 güvenilir, en olumsuz sifat $\% 10,3$ tembel; hakimlik mesleğine atfedilen en olumlu sıfat $\% 35,4$ güvenilir, en olumsuz sıfat \% 7,6 rüşvetçi; avukatlık mesleğine atfedilen en olumlu sifat $\% 9,1$ güvenilir, en olumsuz sıfat \%19,3 rüşvetçi; mühendislik mesleğine atfedilen en olumlu sıfat \%30,9 çalışkan, en olumsuz sıfat \%10,3 güvenilmez; mimarlık mesleğine atfedilen en olumlu sıfat $\% 27,2$ çalışkan, en olumsuz sifat $\% 8,2$ güvenilmez; doktorluk mesleğine atfedilen en olumlu sıfat \%26,6 güvenilir, en olumsuz sıfat \%15,6 rüşvetçi; imamlık mesleğine atfedilen en olumlu sıfat $\% 35,8$ güvenilir, en olumsuz sıfat \% 11,2 tembel; bankacılık mesleğine atfedilen en olumlu sıfat $\% 18,3$ çalışkan, en olumsuz sıfat \%13 rüşvetçi; gazetecilik mesleğine atfedilen en olumlu sifat \%15,9 çalıșkan, en olumsuz sifat \%26,6 güvenilmez; memurluk mesleğine atfedilen en olumlu sıfat \%13,1 çalışkan, en olumsuz sıfat \%21.7 tembel; askerlik mesleğine atfedilen en olumlu sifat $\% 43,8$ güvenilir, en olumsuz sıfat $\% 10,6 \mathrm{kaba}$; hemşirelik mesleğine atfedilen en olumlu sıfat \%14,5 çalışkan, en olumsuz sifat \%28,4 kaba; soförlük mesleğine atfedilen en olumlu sifat \%12,7 çalışkan, en olumsuz sıfat \%38,6 kaba; esnaflık mesleğine atfedilen en olumlu sıfat $\% 13$ çalışkan, en olumsuz sıfat \%17.9 sahtekar; polislik mesleğine atfedilen en olumlu sifat $\% 22,4$ güvenilir, en olumsuz sıfat $\% 32$ rüşvetçi; işçilik mesleğine atfedilen en olumlu sifat \%59,9 çalışkan, en olumsuz sifat \% $\%, 3$ tembel; savcılık mesleğine atfedilen en olumlu sifat $\% 37,8$ güvenilir, en olumsuz sifat $\% 7,4$ güvenilmez; maliyecilik mesleğine atfedilen en olumlu sıfat $\% 6,4$ çalışkan, en olumsuz sıfat \% 44,3 rüşvetçi; müteahhitlik mesleğine atfedilen en olumlu sifat \%3,9 akıllı, en olumsuz sıfat \%50,3 sahtekar olarak bulunmuştur.

3- Mesleklere Atfedilen Olumlu Kalıp Yargıların Dağılımı: Mesleklere atfedilen olumlu kalıp yargıların dağılımına ilişkin bulgular Tablo 3'de verilmiştir.

Tablo 3 Mesleklere Atfedilen Olumlu Kalıp Yargıların Dağılımı

\begin{tabular}{|l|c|}
\hline \multicolumn{1}{|c|}{ Meslekler } & $\%$ \\
\hline öğretmenlik & $\% 7,1$ \\
\hline üniversite hocalığı & $\% 6,7$ \\
\hline işçilik & $\% 6,7$ \\
\hline mimarlık & $\% 6,6$ \\
\hline hakimlik & $\% 6,5$ \\
\hline savcılık & $\% 6,4$ \\
\hline askerlik & $\% 6,2$ \\
\hline imamlık & $\% 6,0$ \\
\hline mühendislik & $\% 5,8$ \\
\hline doktorluk & $\% 5,5$ \\
\hline bankacılık & $\% 4,9$ \\
\hline esnaflık & $\% 3,7$ \\
\hline hemşirelik & $\% 3,7$ \\
\hline avukatlık & $\% 3,5$ \\
\hline polislik & $\% 3,4$ \\
\hline gazetecilik & $\% 3,4$ \\
\hline memurluk & $\% 3,2$ \\
\hline şoförlük & $\% 2,3$ \\
\hline maliyecilik & $\% 1,2$ \\
\hline müteahhitlik & \\
\hline & \\
\hline
\end{tabular}


Mesleklere atfedilen olumlu kalıp yargıların dağılımı Tablo 3'de verilmiştir. Buna göre mesleklere atfedilen olumlu kalıp yargıların dağılımı sırası ile \%7,1 öğretmenlik, \%6,7 üniversite hocalığı ve işçilik, \%6,6 mimarlık, \%6,5 hakimlik, $\% 6,4$ savc1lık, \%6,2 askerlik, \%6 imamlık, \%5,8 mühendislik, \%5,5 doktorluk, $\% 4,9$ bankacilık, \%3,7 esnaflık ve hemşirelik, \%3,5 avukatlık, \%3,4 polislik ve gazetecilik, \%3,2 memurluk, \%2,9 şoförlük, $\% 2,3$ maliyecilik ve $\% 1,2$ müteahhitliktir.

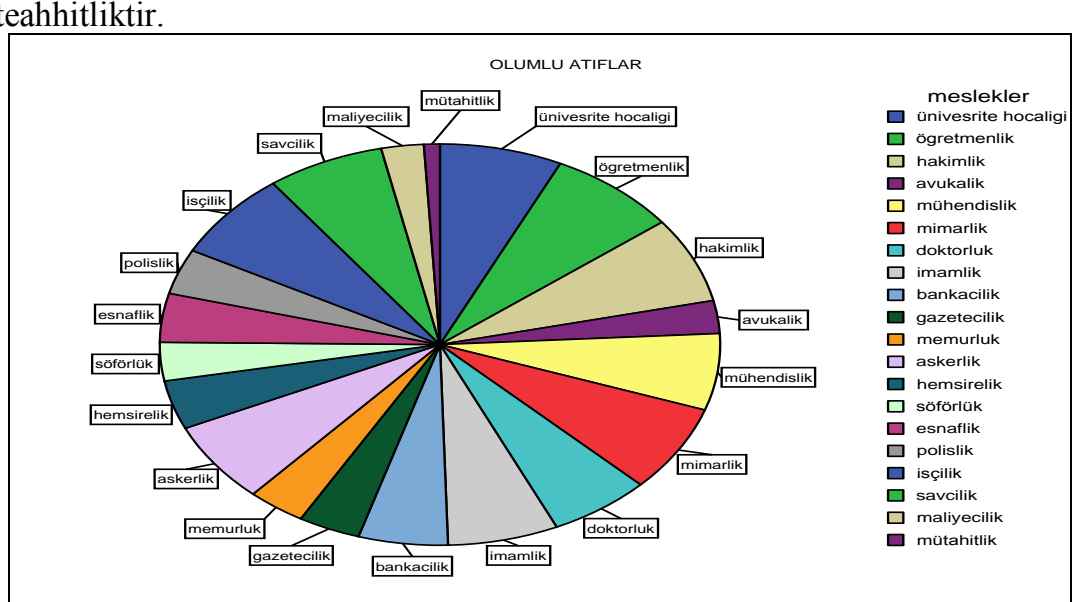

Şekil 2. Mesleklere Atfedilen Olumlu Kalıp Yargıların Dağılımı

4- Mesleklere Atfedilen Olumsuz Kalıp Yargıların Dağılımı: Mesleklere atfedilen olumsuz kalıp yargıların dağılımına ilişkin bulgular Tablo 4 'te verilmiştir.

Tablo 4 Mesleklere Atfedilen Olumsuz Kalıp Yargıların Dağılımı

\begin{tabular}{|l|c|}
\hline \multicolumn{1}{|c|}{ Meslekler } & \% \\
\hline müteahhitlik & $\% 9,1$ \\
\hline maliyecilik & $\% 7,7$ \\
\hline şoförlük, & $\% 7,0$ \\
\hline memurluk, & $\% 6,7$ \\
\hline gazetecilik & $\% 6,4$ \\
\hline polislik & $\% 6,4$ \\
\hline avukatllk & $\% 6,3$ \\
\hline esnaf & $\% 5,8$ \\
\hline hemşirelik & $\% 4,6$ \\
\hline bankacılık & $\% 3,8$ \\
\hline doktorluk, & $\% 3,5$ \\
\hline mühendislik & $\% 3,2$ \\
\hline imamlık & $\% 3,1$ \\
\hline askerlik & $\% 2,8$ \\
\hline savcllık, & $\% 2,6$ \\
\hline hakimlik & $\% 2,5$ \\
\hline mimarlık & $\% 2,4$ \\
\hline üniversite hocalığ & $\% 2,4$ \\
\hline işçilik & $\% 2,0$ \\
\hline öğretmenlik &
\end{tabular}


Mesleklere atfedilen olumsuz kalıp yargıların dağılımı Tablo 4'te incelenmiştir. Buna göre mesleklere atfedilen olumsuz kalıp yargıların dağılımı sirası ile $\% 9,1$ müteahhitlik, $\% 7,7$ maliyecilik, $\% 7$ şoförlük, $\% 6,7$ memurluk, $\% 6,4$ gazetecilik ve polislik, \%6,3 avukatlık, \%6 esnaf ve hemşirelik, \%4,6 bankacılık, $\% 3,8$ doktorluk, $\% 3,5$ mühendislik, $\% 3,2$ imamlık, $\% 3,1$ askerlik, $\% 2,8$ savcılık, $\% 2,6$ hakimlik, \%2,5 mimarlık, \%2,4 üniversite hocalığı ve işçilik ve $\% 2$ öğretmenliktir.

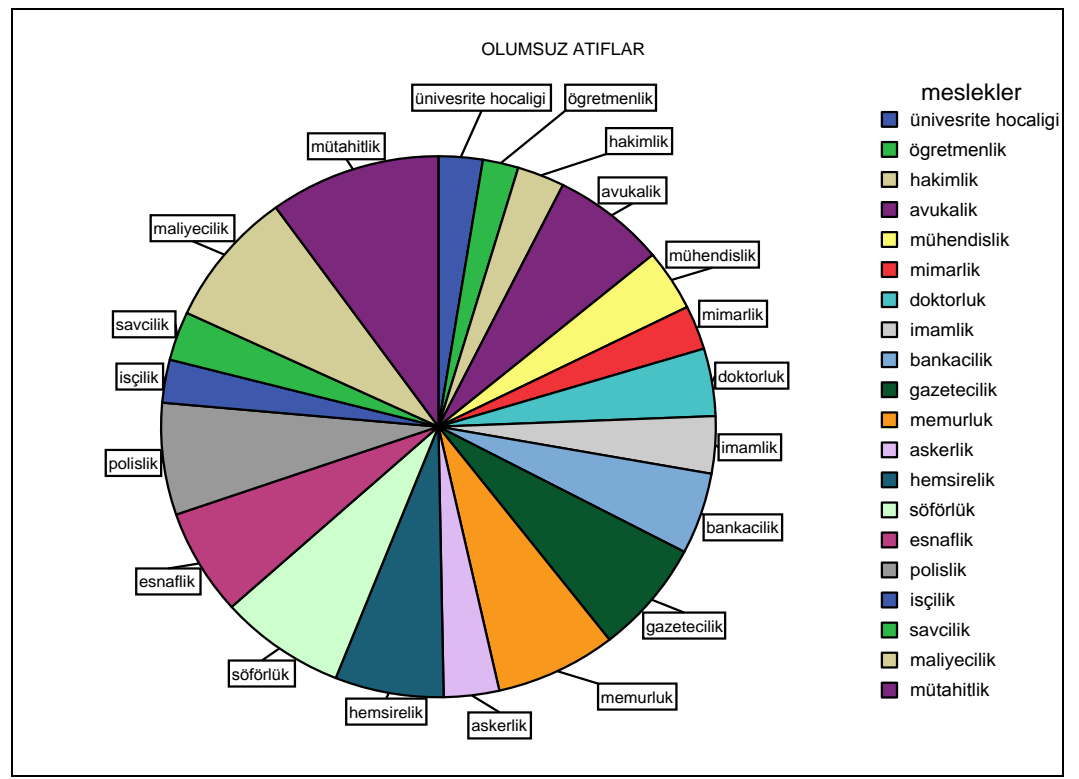

Şekil 3. Mesleklere Atfedilen Olumsuz Kalıp Yargıların Dağılımı

\section{SONUC VE TARTISMA}

Türk insanın meslek mensuplarına karşı kalıp yargılarını (stereotip) belirlemeyi amaçlayan çalışma bulgularına göre; araştırmaya katılan 1161 kişinin toplam işaretlediği sıfatlardan mesleklere yapılan olumlu atıflar, olumsuz atıflara göre daha yüksek orandadır. Bu durum, Türk insanının mesleklere karşı genel olarak ve daha çok olumlu kalıp yargılara sahip olduğunun bir göstergesidir denilebilir. Bunun nedeni olarak, meslek mensuplarının işlerini istenilen düzeyde yaptıkları ve bu nedenle hizmet sunduğu kesimlerce olumlu olarak algılandıkları söylenebilir.

Mesleklere atfedilen kalıp yargıların olumlu olanlarının en çok güvenilir, çalışkan ve akıllı ve olumsuz olanlarının en çok güvenilmez, rüşvetçi ve sahtekar olduğu görülmektedir. Mesleklere atfedilen bu kalıp yargıların hem olumlu ve hem de olumsuz düzeyde olması insanların kendilerini iliş̧kilendirdikleri mesleklerle olan doğrudan yada dolaylı yaşantılarının bir sonucu olabilir. Mesleklere atfedilen hem olumlu ve hem de olumsuz kalıp yargılardaki çelişkinin nedeni, bireyin dolaylı 
yaşantıları sonucu oluşmuş olabilir. Bir bireyin bir meslek mensubu ile yaşadığı bir durumu paylaşan diğer bir birey, bu meslek ile hiçbir bağlantısı olmasa bile o mesleğe ilişkin olumsuz bir kalıp yargı oluşturabilmektedir. Bu durum doğru bilgi ve yaşantıya dayanmaksızın, sorgulamadan ya da araştırma gereği duymadan başkasının dediklerine inanma anlayışının bir sonucu olabilir. Bir anlamda, bir kanıta dayanmadan "şüphe duyma" içinde yaşadığımız kültürde kazanılması gereken bir anlayış̧ır denilebilir. "Babana dahi güvenme" sözü bu durum için bir gösterge niteliğindedir.

Farklı mesleklere atfedilen kalıp yargıların neler olduğuna ilişkin elde edilen sonuçlara göre; en çok güvenilir olarak algılanan meslekler, askerlik, savcılık, imamlık, hakimlik, öğretmenlik ve üniversite hocalığı; en çok kibar olarak algılanan meslekler, bankacılık, hemşirelik, üniversite hocalığı ve mimarlık; en çok cömert olarak algılanan meslekler doktorluk, bankacılık, hakimlik ve üniversite hocalığı; en çok akıllı olarak algılanan meslekler, üniversite hocalığı, mimarlık, mühendislik ve öğretmenlik; en çok dürüst olarak algılanan meslekler, imamlık, hakimlik, savcılık, öğretmenlik ve askerlik; en çok çalışkan olarak algılanan meslekler, işçilik, mühendislik, mimarlık ve öğretmenlik; en çok rüşvetçi olarak algılanan meslekler, maliyecilik, polislik, avukatlık, memurluk ve doktorluk; en çok tembel olarak algılanan meslekler memurluk ve imamlık; en çok güvenilmez olarak algılanan meslekler gazetecilik, müteahhitlik, esnaflık ve avukatlık; en çok sahtekar olarak algılanan meslekler müteahhitlik, avukatlık, esnaflık ve gazetecilik; en çok saldırgan olarak algılanan meslekler, hemşirelik, gazetecilik, şoförlük ve polislik; en çok kaba olarak algılanan meslekler şoförlük, hemşirelik, esnaflık ve memurluk olduğu bulunmuştur. Gen bilim (2007) tarafindan Türkiye genelinde yapılan araştırma sonuçlarına göre, meslek mensuplarının dürüstlük puanları en yüksek olan meslekler öğretmenlik ve subaylık meslekleridir. Dürüstlük puanı düşük olan meslek grupları ise polislik, vergi ve gümrük memurlarıdır.

Türk insanının meslek mensuplarına atfettiği olumlu kalıp yargıların mesleklere göre dağılımı sırası ile; öğretmenlik, üniversite hocalığı, işçilik, mimarlık, hakimlik, savcılık, askerlik, imamlık, mühendislik, doktorluk, bankacılık, esnaflık, hemşirelik, avukatlık, polislik, gazetecilik, memurluk, şoförlük, maliyecilik ve müteahhitlik meslekleri olduğu görülmektedir. Meslek mensuplarına atfedilen olumsuz kalıp yargıların mesleklere göre dağılımı sırası ile müteahhitlik, maliyecilik, şoförlük, memurluk, gazetecilik, polislik, avukatlık, esnaflık, hemşirelik, bankacılık, doktorluk, mühendislik, imamlık, askerlik, savcılık, hakimlik, mimarlık, üniversite hocalığı, iş̧ilik ve öğretmenlik meslekleri olduğu görülmektedir. Mesleklere atfedilen kalıp yargıların olumlu ya da olumsuz olması yapılan işin niteliği ve hizmet sunduğu kesimin özellikleri ile açıklanabilir. İnsana doğrudan hizmet veren mesleklerde müşteri memnuniyetinin çok zor olması ve müşterilerin beklentileri ile alınan hizmetin düzeyi arasındaki farlılıklar bu sonuçları doğurmuş olabilir. Bir diğer neden ise, bu hizmetlerden yararlanma durumunda olan insanlara yönelik yapılan farklı uygulama biçimleri olabilir. Mesleklere karşı atfedilen olumlu kalıp yargıların, temelde bütün meslekleri yürüten bireylerin 
mesleki kimliklerinde olması gereken özellikler, olumsuz kalıp yargıların ise hiçbir meslekle bağdaştırılmayacak atıflar olduğu görülmektedir.

$\mathrm{Bu}$ özelliklere uygun davranmamanın nedenleri, bir mesleğe yönlendirme sürecin başından itibaren dikkate alınmalıdır. $\mathrm{Bu}$ süreç ilköğretim yıllarında yapılacak profesyonel ve uygun yönlendirmeler ile başlayan, mesleki eğitim programının içeriğine uygun anlayışla yetiştirme ve mesleği icra etmeyle devam eden bir süreçtir. Birey daha ilköğretim yıllarından başlayarak mesleki kimliğini oluşturmaya başlamalı ve bu kimliğe uygun davranışları mesleğinde otomatik olarak ortaya koyar hale gelmelidir. Birey hiç zorlanmadan, adeta bir reflekssel biçimde mesleğine uygun olan ve olmayan davranışlarının hemen farkında olma ve ona göre ortaya koyma yeterliliğine sahip olmalıdır.

Sonuç olarak eğitim sürecinde, ilköğretim düzeyinden itibaren birey, yaptığı davranışın kendi mesleği ile ne kadar örtüşüp örtüş̧mediğini ve davranışlarının hizmet ettiği kesime bunun yansımalarını değerlendirir yeterlikte yetiştirilmelidir. Ayrıca, bireyi bir mesleğe yönlendirmede ve mesleğe eleman seçmede kişilik özellikleri de belirleyici bir faktör olarak dikkate alınmalıdır. Bireyi bir mesleğe yönlendirme işinin daha sistemli ve profesyonelce yapılarak, bütün ilgili kişi, kurum ve kuruluşlarda ortak bir anlayış oluşturulmalıdır. Mesleki eğitim programlarında sadece bir mesleğe ait bilgi ve beceriler kazandırmaya ağırlık verilmemeli, o mesleğe ilişkin tutum oluşturma ve bir mesleki kimlik kazandırmaya ilişkin gerekli hedefldavranışlar, içerik ve öğrenme yaşantılarına yer verilmelidir. Özellikle doğrudan insana hizmet veren meslekler için, eğitim programlarında iletişim becerilerine yönelik hedefldavranışlar yer almalıdır. Bu çalışmayla ilişkili olarak, bir diğer araştırma meslek mensuplarının bağlı oldukları kurumlara yönelik yapilmalıdır. 
KAYNAKLAR

Atkinson, L. R. ve diğ. (2002). Psikolojiye Giriş (Çev: Y. Alogon). Ankara: Arkadaş Yayınları,

Amerikan Psikiyatri Birliği. (1995). Mental Bozuklukların Tanısal ve Sayımsal El Kitabl, (DSM-IV) Washington, Dc.: Amerikan Psikiyatri Birliği,

Bilgin, N. (1995). Sosyal Psikolojiye Giriş. İzmir: Mart Matbaacılık.

Budak, S. (2003). Psikoloji Sözlüğ̈̈. Ankara: Bilim ve Sanat Yayınları.

Büyük Larousse. (Tarihsiz). Sözlük ve Ansiklopedisi. Cilt 17. İstanbul: Milliyet Basım.

Cüceloğlu, D. (2000). Insan Ve Davranışı. İstanbul: Remzi Kitapevi.

Doğan, İ. (2007). Sosyoloji: Kavramlar ve Sorunlar. Ankara: PegamA Yayıncılık.

Doğramacı, M. (2008). Meslek seçimi. http://www.geocities.com/egitimcilersitesi rehberlik/, (01.02.2008' de indirildi).

Dönmez, A. (1989). Sosyal Psikoloji. İstanbul: Ara Yayıncılık.

Ergun, M. (1994). Eğitim sosyolojisine Giriş. Ankara: Ocak yayınları.

Foulquie, P. (1994). Pedagoji Sözlüğü. (Çev: C. Karakaya). İstanbul: Sosyal Yayınları.

GenBilim. (2008). Makaleler. http://www.genbilim.com/content/view/, (31.01.2008'de indirildi).

Hogg, M. A. \& Vaughạn, G. M. (2007). Sosyal Psikoloji. (Çev: İ. Yıldız ve A. Gelmez). Ankara: Ütopya Yayınevi.

Index. (2008). Meslek ile iş arasındaki fark nedir? http://www.index.gen.tr/, (31.01.2008' de indirildi).

Kağıtçıbaşı, Ç. (1985). Insan ve Insanlar. İstanbul: Beta Basım.

Karabayev, B. ve Tutkun, Ö. F. (2001). Türk Cumhuriyetlerinde Gelen Öğrencilerin Türkiye Cumhuriyeti Vatandaşlarına Karşı Taşıdıkları Kalıp Yargılar. Bilig, $18,1-26$.

Kuzgun, Y. (1982). Mesleki Rehberliğin Bireyin Yetenek ve Illgilerine Uygun Meslekleri Tanımalarına Etkisi. Ankara: Ankara Üniversitesi Yayınları.

Kuzgun, Y. (2008). Meslek Seçiminde Bilinmesi Gerekenler. http://www.gopaml.k12.tr/, (29.02.2008'de indirildi).

Meslek Rehberi. (2008). Meslek. http://www.meslekrehberi.org/meslek/, (01.02.2008'de indirildi).

Meslek Seçimi. (2008). Meslek Seçiminde Gözetilecek Hususlar. http://w3.gazi.edu.tr/ aligullu/, (28.02.2008'de indirildi).

ÖSSS Rehberi. (2008). Meslek Rehberi. http://www.tebesir.com/ossrehberi/, (01.03.2008'de indirildi).

PsikoWeb. (2008). Mesleki Rehberlik Nedir? http://www.psikoweb.com/, (02.01.2008'de indirildi).

Robertson, I. (1987). Sociology. New York: Worth Publishers,

Rycroft, C. (1989). Psikanaliz Sözlüğü. (Çev: S. Kayatekin). İstanbul: Ara Yayınc1lik.

Şahin, A. E. (2006). Meslek Ve Öğretmenlik, V. Sönmez (Ed.) Eğitim Bilimine Giriş (s.261-306). Ankara: Anı Yayıncılık.

Şerif, M. ve Şerịf, C. W. (1996). Sosyal Psikolojiye Giriş I-II. (Çev: M. Atakay ve A. Yavuz). İstanbul: Sosyal Yayinlar.

Türkiye Odalar ve Borsalar Birliği (TOBB). (2008). Mesleklerin Gruplandırılması Rehberi. http://www.tobb.org.tr/, (01.03.2008'de indirildi).

Yılmaz, B. (2002). Öğretmenlik Nasıl Bir Meslektir?, A. M. Sünbül (Ed.) Eğitime Yeni Bakışlar (s.308-322). Ankara: Mikro Yayınları. 